\title{
Krzysztof Kędziora
}

Instytut Filozofii

Uniwersytet Łódzki

kedziora@filozof.uni.lodz.pl

\section{REAKCJE ŚRODOWISK AKADEMICKICH NA USTAWE LUSTRACYJNA}

\begin{abstract}
Abstrakt
Artykuł przedstawia reakcję środowisk akademickich na tzw. ustawę lustracyjną, zarówno akademickich ciał kolegialnych, jak i poszczególnych przedstawicieli środowiska uniwersyteckiego. Prezentowana argumentacja - przeciwników i zwolenników ustawy lustracyjnej - ma charakter formalno-prawny oraz moralny. Artykuł stara się wiernie oddać złożony obraz reakcji środowisk akademickich na ustawę lustracyjną.
\end{abstract}

\section{Słowa kluczowe}

życie akademickie w Polsce, lustracja, odpowiedzialność za przeszłość

Nowelizacja ustawy z dnia 18 października 2006 r. o ujawnianiu informacji o dokumentach bezpieczeństwa państwa z lat 1944-90 oraz treści tych dokumentów przeprowadzona 14 lutego 2007 r. (zwana dalej ustawą lustracyjną) wzbudziła w środowisku akademickim żywą dyskusję. Niniejszy tekst zdaje relację z publicznej debaty na temat lustracji środowisk akademickich. Uwzględnia on tylko publiczne oświadczenia instytucji akademickich oraz poszczególnych przedstawicieli środowiska akademickiego i obejmuje okres od uchwalenia nowelizacji ustawy po uznanie niekonstytucyjności części jej przepisów przez Trybunał Konstytucyjny 11 maja 2007 r. Tekst ten daleki jest od uwzględnienia wszystkich głosów, lecz, na tyle na ile było to możliwe, przedstawia najważniejsze racje za i przeciw ustawie lustracyjnej.

W sprawie ustawy lustracyjnej jako jedni z pierwszych głos zabrali członkowie Rady Wydziału Prawa i Administracji Uniwersytetu Warszawskiego, podejmując uchwałę z dnia 19 marca 2007 r. w sprawie zagrożeń dla de- 
mokratycznego państwa prawnego ${ }^{1}$ oraz zajmując stanowisko w sprawie ustawy lustracyjnej ${ }^{2}$. Należy podkreślić znaczenie tych oświadczeń z dwóch powodów. Po pierwsze dlatego, że sformułowano w nich szereg fundamentalnych i następnie często powtarzanych zarzutów, głównie natury prawno-konstytucyjnej, pod adresem rzeczonej ustawy. Po drugie dlatego, że uchwała Rady Wydziału Prawa i Administracji UW stanowiła punkt odniesienia dla wielu podobnych dokumentów, w tym przede wszystkim uchwał Senatu Uniwersytetu Warszawskiego $^{3}$, które cieszyły się dużym poparciem w polskim środowisku akademickim i stanowiły punkt odniesienia dla wielu, $\mathrm{z}$ ducha podobnych, oświadczeń ciał kolegialnych innych ośrodków akademickich.

W podjętej uchwale w sprawie zagrożeń dla demokratycznego państwa prawnego Rada Wydziału Prawa i Administracji Uniwersytetu Warszawskiego wyraziła zaniepokojenie stanem życia politycznego i społecznego w Polsce: instrumentalizacją prawa, ,zawłaszczeniem” instytucji publicznych, ideologizacją życia społecznego i gospodarczego, ograniczaniem niezależności mediów, pogarszającą się jakością stanowionego prawa i atakami na autorytet Trybunału Konstytucyjnego oraz sądów, likwidacją służby publicznej, prawnymi nadużyciami (nierespektowaniem zasady domniemania niewinności, nadużywaniem instytucji tymczasowego aresztowania, nieposzanowania godności aresztowanych), upolitycznieniem prokuratury. Szczególnym przejawem tego stanu rzeczy jest, w opinii Rady Wydziału Prawa i Administracji UW, kształt procesu lustracyjnego. „Przepisy obowiązującej obecnie ustawy lustracyjnej - czytamy w uchwale - nasuwają poważne wątpliwości etyczne i konstytucyjne" ${ }^{\text {. }}$. W konsekwencji ustawa ta prowadzi do ,podważenia fundamentów demokratycznego państwa prawnego, zasad społeczeństwa obywatelskiego oraz do obniżenia standardów życia społecznego",

Środowisko prawnicze Uniwersytetu Warszawskiego podniosło szereg szczegółowych zastrzeżeń natury prawno-konstytucyjnej pod adresem ustawy lustracyjnej:

1. Ustawa lustracyjna wprowadza dwa tryby lustracji. Pierwszy z nich, któremu podlegać mają osoby wykonujące określone zawody i pełniące określone

\footnotetext{
${ }^{1}$ Uchwała Rady Wydziału Prawa i Administracji UW z dnia 19 marca 2007 r. w sprawie zagrożeń dla demokratycznego państwa prawnego, http://wyborcza.pl/1,79328,3999054.html [dostęp 23.12.2014].

${ }^{2}$ Stanowisko Rady Wydzialu Prawa i Administracji Uniwersytetu Warszawskiego z dnia 19 marca 2007 r.w sprawie tzw. ustawy lustracyjnej, http://wyborcza.pl/1,79328,4003768.html [dostęp 23.12.2014].

${ }^{3}$ Uchwała $\mathrm{nr} 181$ z dnia 21 marca $2007 \mathrm{r}$. w sprawie zagrożeń dla demokratycznego państwa prawnego oraz Uchwała nr 182 z dnia 21 marca 2007 r. w sprawie tzw. ustawy lustracyjnej.

${ }^{4}$ Uchwała Rady Wydzialu Prawa i Administracji Uniwersytetu Warszawskiego z dnia 19 marca 2007 r. w sprawie zagrożeń dla demokratycznego państwa prawnego, op. cit.

${ }^{5}$ Ibidem.
} 
funkcje, polega na złożeniu odpowiednich oświadczeń. Osoby, które ich nie złożą lub których oświadczenie nie będzie zgodne z prawdą, podlegać będą określonym przez ustawę sankcjom. Drugi tryb lustracji polegać ma (według ustawy) na upublicznieniu przez Instytut Pamięci Narodowej dokumentów dotyczących osób, które w takiej czy innej formie współpracować miały z organami bezpieczeństwa PRL. Sytuacja taka powoduje, że osoby objęte lustracją w pierwszym trybie podlegać będą także lustracji w drugim trybie, przez pewien czas jednak ,znajdą się w sytuacji swoistej pułapki prawnej. Działać będą bowiem w stanie czasowego braku wiedzy co do zawartości IPN na swój temat"6. Taka sytuacja nie dotyczy osób objętych ustawą tylko w drugim trybie. „Godzi to $\mathrm{w}$ zasadę zaufania obywatela do państwa. Uregulowania normatywne demokratycznego państwa prawnego nie mogą sięgać po takie środki oddziaływania na obywateli"”.

2. Ustawa lustracyjna zbyt szeroko i jednocześnie arbitralnie określa zakres osób, które miały podlegać lustracji. Zostały nią objęte nie tylko osoby zajmujące stanowiska lub wykonujące zawody zaufania publicznego. Objęcie innych (niepełniących takich funkcji) osób wymogami nałożonymi przez ustawę miało arbitralny charakter, bez wskazania wyraźnych kryteriów.

3. Ustawa narusza zasady wolności słowa i wolności mediów poprzez zaliczenie do grona osób podlegających lustracji dziennikarzy i określenie sankcji zakazu wykonywania zawodu w następstwie niepodporządkowania się obowiązkowi lustracyjnemu lub złożenia fałszywego oświadczenia. Potraktowanie tejże sankcji ,zgodnie z brzmieniem ustawy oznacza podmiotowy zakaz wszelkich publikacji przez dziesięć lat, w stosunku do wszystkich osób piszących, z wyjątkiem autorów książek. Realizacja takiego zakazu łamie zasadę wolności słowa i ustanawia swoistego rodzaju cenzurę, której istnienie jest konstytucyjnie zabronione" ${ }^{\text {. }}$.

4. Niektóre przepisy ustawy mają charakter retroaktywny. „Dotyczy to w szczególności zaliczenia, z mocą wsteczną, do organów bezpieczeństwa państwa Urzędu do Spraw Wyznań wraz jego organami terenowymi"’.

5. Ustawa narusza zasadę prawną mówiącą o tym, iż nikt nie może być zmuszony do przedstawiania dowodów przeciwko sobie, a także „rodzi

\footnotetext{
${ }^{6}$ Stanowisko Rady Wydziatu Prawa i Administracji Uniwersytetu Warszawskiego z dnia 19 marca 2007 r. w sprawie tzw. ustawy lustracyjnej, op. cit.

${ }^{7}$ Ibidem.

${ }^{8}$ Ibidem.

${ }^{9}$ Ibidem.
} 
wątpliwości z punktu widzenia art. 30 Konstytucji RP, gwarantującego poszanowanie godności człowieka"10.

6. Sankcje przewidziane $\mathrm{w}$ ustawie, szczególnie za niezłożenie oświadczenia lustracyjnego, „są nieproporcjonalnie surowe w stosunku do celu, jakiemu ma służyć ustawa”"11. Co więcej, takie sankcje jak „pozbawienie biernego prawa wyborczego oraz zakaz zajmowania określonego stanowiska, wykonywania określonego zawodu lub prowadzenia określonej działalności jest możliwe jako środek karny, orzeczony jedynie przez sąd w konsekwencji popełnienia przestępstwa" ${ }^{\prime 2}$.

7. Skala lustracji, czyli ilość osób nią objętych, spowoduje naruszenie art. 45 Konstytucji RP, który mówi: „Każdy ma prawo do sprawiedliwego i jawnego rozpatrzenia sprawy bez nieuzasadnionej zwłoki przez właściwy, niezależny, bezstronny i niezawisły sąd".

8. Ustawodawca przewidział zbyt krótki czas na wejście ustawy w życie, co „uniemożliwia jej zbadanie pod względem zgodności z konstytucją przez Trybunał Konstytucyjny przed dniem, w którym przystąpiono do jej wykonania" 13 .

9. Wprowadzenie w życie ustawy wiąże się z niebezpieczeństwem naruszenia wolności badań naukowych i autonomii szkół wyższych, które wynika „z możliwości odsunięcia nauczycieli akademickich od pracy zawodowej (nawet badawczej) oraz $\mathrm{z}$ ograniczenia samodzielności uczelni $\mathrm{w}$ doborze pracowników naukowo-dydaktycznych" ${ }^{\text {"14 }}$.

10. Wielka liczba oświadczeń może uniemożliwić ich pełną weryfikację, szczególnie w krótkim czasie. „Nie jest wykluczone zatem, że mimo uregulowań zawartych w ustawie określających kolejność, w jakiej w stosunku do poszczególnych grup osób lustrowanych podejmowane będą czynności sprawdzające, będzie to w praktyce weryfikacja wybiórcza, co stwarza niebezpieczeństwo stronniczości. Brak jest ponadto instrumentów efektywnej kontroli bezstronności działania IPN w tej sprawie" ${ }^{\text {"15 }}$.

11. W punkcie ostatnim swoich zarzutów prawnicy $\mathrm{z}$ Uniwersytetu Warszawskiego wskazali na inne pomniejsze niedociągnięcia i niejasności prawne ustawy lustracyjnej (np. nieokreślenie trybu, w jakim ma następować

\footnotetext{
${ }^{10}$ Artykuł 30 Konstytucji RP stwierdza, że „Przyrodzona i niezbywalna godność człowieka stanowi źródło wolności i praw człowieka i obywatela. Jest ona nienaruszalna, a jej poszanowanie i ochrona jest obowiązkiem władz publicznych".

${ }^{11}$ Stanowisko Rady Wydzialu Prawa i Administracji Uniwersytetu Warszawskiego z dnia 19 marca 2007 r. w sprawie tzw. ustawy lustracyjnej, op. cit.

${ }^{12}$ Ibidem.

${ }^{13}$ Ibidem.

${ }^{14}$ Ibidem.

${ }^{15}$ Ibidem.
} 
rozwiązanie stosunku pracy z osobą, która nie złożyła oświadczenia lustracyjnego lub okazało się, że jest ono fałszywe).

Stanowisko członków Rady Wydziału Prawa i Administracji Uniwersytetu Warszawskiego zostało potwierdzone przez dwie uchwały Senatu tegoż Uniwersytetu. W pierwszej z nich, uchwale nr 181 z dnia 21 marca 2007 r. w sprawie zagrożeń dla demokratycznego państwa prawnego ${ }^{16}$, Senat UW wyraził te same obawy dotyczące istniejących zagrożeń dla porządku prawnego w Polsce, co Rada Wydziału Prawa i Administracji UW, a mianowicie takie jak instrumentalizacja prawa, ,zawłaszczanie” instytucji publicznych, itd. W drugiej uchwale, uchwale nr 182 z dnia 21 marca 2007 r. w sprawie tzw. ustawy lustracyjnej ${ }^{17}$, Senat UW powtórzył prawno-konstytucyjne zarzuty pod adresem ustawy lustracyjnej. Uznał mianowicie, że:

wątpliwości budzi zwłaszcza wprowadzony przez ustawę zakaz wykonywania funkcji publicznych z powodu niezłożenia oświadczenia, który to zakaz narusza konstytucyjnie gwarantowaną wolność nauczania i badań naukowych. Ustawa lustracyjna stanowi, naszym zdaniem, naruszenie prawa do pracy. Pozbawia ona takiego prawa osoby, w przypadku których nie ma żadnego związku między ich przeszłością lub niezłożeniem oświadczenia lustracyjnego a wykonywaną pracą. Nikt nie może być także zobowiązany do świadczenia przeciw sobie, a samo oświadczenie nie może stanowić dowodu winy. Żaden organ władzy publicznej, w tym Instytut Pamięci Narodowej, nie może upubliczniać informacji osobowych bez możliwości sprzeciwu zainteresowanej osoby i nie może odmówić tej osobie dostępu do dokumentów jej dotyczących. Ustawa narusza prawo do rzetelnego procesu ${ }^{18}$.

Senat UW, wobec powyższych wątpliwości, wyraził przekonanie, iż należy wstrzymać wszelkie czynności związane z wykonaniem rzeczonej ustawy i zaapelował do Rzecznika Praw Obywatelskich, by podją odpowiednie kroki w tym zakresie. Senat UW zwrócił się do Prezydenta, Senatu i Sejmu, aby wystąpili w trybie pilnym z inicjatywą nowelizacji ustawy, tak by przynajmniej zawiesić jej wykonanie do czasu orzeczenia jej zgodności z Konstytucją RP.

Stanowisko Senatu spotkało się ze sprzeciwem części pracowników naukowych Uniwersytetu Warszawskiego (popartego przez kilkudziesięciu pracowników naukowych z innych ośrodków akademickich), którzy wystosowali list „Odpowiedź na uchwałę Senatu Uniwersytetu Warszawskiego"

\footnotetext{
${ }^{16}$ Uchwała $n r 181$ z dnia 21 marca 2007 r. w sprawie zagrożeń dla demokratycznego państwa prawnego, http://www.monitor.uw.edu.pl/Lists/Uchway/Attachments/1899/M.2007.199.U.181.pdf [dostęp 23.12.2014].

17 Uchwata $\mathrm{nr} 182$ z dnia 21 marca 2007 r. w sprawie tzw. ustawy lustracyjnej, http:// www.monitor.uw.edu.pl/Lists/Uchway/Attachments/1900/M.2007.200.U.182.pdf [dostęp 23.12.2014].

${ }^{18}$ Ibidem.
} 
z 23 marca 2007 r. ${ }^{19}$ Jego inicjatorem był między innymi prof. Andrzej Chojnowski z Instytutu Historycznego UW, członek Kolegium Instytutu Pamięci Narodowej, następnie jego przewodniczący i członek Rady IPN. List został podpisany przez kilkudziesięciu przedstawicieli różnych środowisk akademickich $\mathrm{z}$ całej Polski. Jego sygnatariusze podzielają wyrażoną przez Senat UW w uchwale nr 181 troskę o stan życia publicznego w Polsce, a także uznają zasadność podniesionych pod adresem ustawy lustracyjnej w uchwale nr 182 zastrzeżeń prawnych, lecz nie traktują ich jako dyskwalifikujących i uprawniających do obywatelskiego nieposłuszeństwa, bowiem „występujące niedoskonałości ustaw nie mogą $\mathrm{w}$ demokratycznym państwie prawa prowadzić do podejmowania działań stanowiących de facto zachętę do nieposłuszeństwa prawu” ${ }^{20}$. Co więcej, podkreślają, iż stanowisko Senatu UW „niepotrzebnie wikła środowisko akademickie w bieżące spory polityczne. Sugeruje ono jednocześnie jego jednolitą postawę wobec istotnych problemów kraju, co nie jest zgodne z rzeczywistością. Apel o poparcie tego stanowiska uważamy za próbę sztucznego ujednolicenia poglądów politycznych pracowników naukowych i wywieranie presji na tych spośród nas, którzy diagnozy Senatu UW nie podzielają"21. Sygnatariusze listu podkreślili zasadność i konieczność lustracji, argumentując (za uchwałą Senatu UJ z roku 2005), iż współpraca $\mathrm{z}$ organami bezpieczeństwa PRL jest niegodna nauczyciela akademickiego.

Stanowisko Senatu UW zostało z kolei poparte przez Radę Wydziału Filozoficznego Uniwersytetu Jagiellońskiego w uchwale z 27 marca 2007 r. ${ }^{22}$ Czytamy w niej, że Rada Wydziału Filozoficznego UJ nie ma zamiaru:

ukrywać ani usprawiedliwiać osób, które dopuściły się moralnie nagannej współpracy z organami służby bezpieczeństwa. Jednakże obecnie obowiązująca ustawa lustracyjna, która miałaby umożliwiać ujawnienie i pociągnięcie do odpowiedzialności sprawców tych przewinień, w istocie nie spełnia swojego zadania, budzi natomiast poważne wątpliwości natury etycznej i prawnej, uwłacza godności człowieka, obywatela i pracownika nauki, może wyrządzić krzywdę wielu niewinnym osobom, które zostaną niesłusznie napiętnowane, jak również narusza autonomię wyższych uczelni ${ }^{23}$.

Także Senat UJ w uchwale z dnia 28 marca 2007 r. $^{24}$ podzielił wątpliwości i zastrzeżenia wyrażone przez Radę Wydziału Prawa i Administracji oraz Senat

\footnotetext{
19 Odpowiedź na uchwate Senatu Uniwersytetu Warszawskiego, https://nfa.pl/news.php?id= 5416\&PHPSESSID=a90dd83a03a16a5b0498ae060a424df7 [dostęp 23.12.2014].

${ }^{20}$ Ibidem.

${ }^{21}$ Ibidem.

${ }^{22}$ Uchwata Rady Wydziału Filozoficznego Uniwersytetu Jagiellońskiego z 27 marca 2007 r., http://wyborcza.pl/1,79328,4018318.html [dostęp 23.12.2014].

${ }^{23}$ Ibidem.

${ }^{24}$ Uchwata Senatu Uniwersytetu Jagiellońskiego z 28 marca 2000 r., http://wyborcza.pl/ 1,79328,4022659.html [dostęp 23.12.2014].
} 
Uniwersytetu Warszawskiego. W uchwale czytamy ponadto: „akty prawne dotyczące oceny wydarzeń historycznych nie powinny stawiać obywateli przed koniecznością wyboru pomiędzy posłuszeństwem prawu a wiernością zasadom, o które w przeszłości walczyli”,25. Senat UJ wezwał do merytorycznej i pozbawionej agresji „dyskusji o zasadniczym znaczeniu dla funkcjonowania instytucji Państwa i życia społeczeństwa"26.

Przeciwko stanowisku Senatu UJ zaprotestowało kilkudziesięciu naukowców z tegoż Uniwersytetu. W „Liście otwartym w sprawie lustracji na UJ”27 sygnatariusze listu informują publicznie, że „w związku $\mathrm{z}$ aktywnością przeciwników składania oświadczeń lustracyjnych, starających się sprawić wrażenie, iż wszyscy pracownicy naukowi podzielają ich stanowisko”, złożyli „takie oświadczenia, nie czując żadnej niedogodności z tym związanej”"28. Następnie wyjaśniają powody swojego postępowania:

a uczyniliśmy tak nie tylko z tego powodu, że nie mamy się czego wstydzić, ale przede wszystkim dlatego, iż uważamy, że tak pracodawca, jak młodsi koledzy i studenci mają prawo wiedzieć, jak postępowaliśmy niegdyś jako osoby prywatne oraz jako nauczyciele akademiccy związani etyką zawodową i obywatelską $^{29}$.

Dalej czytamy, że wśród przeciwników lustracji wyróżnić można dwie grupy ludzi. Do pierwszej należą ci, którzy przeciwstawiają się jej z powodów ideowych. „Nie przeszkadza im konieczność informowania władz o różnych aspektach życia prywatnego i publicznego, lecz polecenie złożenia oświadczenia na temat tego, czy współpracowali z organami represji Polski komunistycznej, wywołuje wewnętrzny opór"30. Do drugiej grupy natomiast należą ci, którzy „kiedyś okazali słabość, starając się wszelako nie szkodzić innym, jak również tacy, którzy działając ze zgoła nieszlachetnych powodów, wyrządzili swoim kolegom krzywdę" "31. Sygnatariusze listu uważają jednak, że na wykładowcach wyższej uczelni, szczególnie tak zasłużonej jak Uniwersytet Jagielloński, spoczywa wielka odpowiedzialność za to, co czynią obecnie i za to, co czynili w przeszłości, a więc powinni się świadomie poddać procedurze lustracyjnej ${ }^{32}$.

\footnotetext{
25 Ibidem.

26 Ibidem.

${ }^{27}$ http://wyborcza.pl/1,79328,4033504.html [dostęp 23.12.2014].

28 Ibidem.

${ }^{29}$ Ibidem.

${ }^{30}$ Ibidem.

${ }^{31}$ Ibidem.

${ }^{32}$ Warto odnotować odpowiedź na List otwarty $w$ sprawie lustracji na UJ autorstwa prof. Jana Woleńskiego (http://wyborcza.pl/1,79328,4053937.html [dostęp 23.12.2014]). Lustracji prof. Jan Woleński poświęcił także książkę Lustracja jako zwierciadło, Universitas, Kraków 2007.
} 
Konferencja Rektorów Uniwersytetów Polskich ${ }^{33}$ opowiedziała się natomiast przeciwko lustracji w jej określonej ustawą postaci. Oprócz zastrzeżeń natury formalnoprawnej pod adresem ustawy lustracyjnej podkreślono, że godzi ona w autonomię szkół wyższych i swobodę prowadzenia badań naukowych oraz stoi w sprzeczności z ustawą Prawo o szkolnictwie wyższym. Konferencja Rektorów Uniwersytetów Polskich w zakończeniu swojego stanowiska wyraziła nadzieję, że „rozstrzygnięcia Trybunału Konstytucyjnego doprowadzą do nowelizacji ustawy lustracyjnej usuwającej jej wątpliwe zapisy prawne, a równocześnie wyraża żal, że terminy realizacji ustawy praktycznie uniemożliwiają nadzór Trybunału Konstytucyjnego nad tworzonym prawem, które dotyczy setek tysięcy obywateli" ${ }^{34}$.

Rada Naukowa Instytutu Badań Literackich PAN dnia 20 marca 2007 r. podjęła uchwałę o wstrzymaniu akcji lustracyjnej w obecnym kształcie ${ }^{35}$ (podobną w treści uchwałę podjęło także Prezydium Polskiej Akademii Nauk ${ }^{36}$ ) i wskazując m.in. na zagrożenie dla państwa prawa oraz dla autonomii szkół wyższych i Polskiej Akademii Nauk, jakie niesie ze sobą ustawa lustracyjna, wyraziła zrozumienie dla idei lustracji, która powinna „obejmować osoby aspirujące do objęcia funkcji i stanowisk politycznych”. Lustracja nie powinna jednak mieć charakteru prawnego i to szczególnie przy pomocy źle skonstruowanego prawa:

[...] osąd PRL-owskiej przeszłości powinien się dokonać, jednakże w wymiarze moralnym, historycznym i politycznym. W osiemnaście lat po odzyskaniu przez Polskę niepodległości lustrację wprowadzaną ustawą, której przepisy są nieprecyzyjne, nie respektują zasady równości obywateli wobec prawa, a ponadto kierują się kryteriami oceny stosowanymi przez PRL-owskie służby bezpieczeństwa (np. „osoba zaufana” jako jedna z kategorii współpracy), uważamy za chybioną ${ }^{37}$.

Podobne do powyższych stanowiska zajęły także inne ośrodki akademickie w Polsce (m.in. Akademia Świętokrzyska, ASP w Warszawie, ASP we Wrocławiu, Uniwersytet Wrocławski, Uniwersytet Gdański, Uniwersytet Warmińsko-Mazurski).

\footnotetext{
${ }^{33}$ Stanowisko 175 Konferencji Rektorów Uniwersytetów Polskich z dnia 23 marca 2007 roku w sprawie tzw. ustawy lustracyjnej. https://www.umk.pl/uczelnia/dokumenty/biuletyn/prawo/inc/ zalaczniki/Uchwala_17_2007_z1.pdf [dostęp 23.12.2014]. Stanowisko to zostało między innymi poparte przez Senat UAM w uchwale $\mathrm{nr} 17 \mathrm{z}$ dnia 27 marca 2007 roku, http://www.umk.pl/ uczelnia/dokumenty/biuletyn/prawo/?akcja $=$ dokument\&typ $=$ Uchwaly\&nr $=17 \& b p=0 \&$ rok $=2007$ [dostęp 23.12.2014].

${ }^{34}$ Ibidem.

${ }^{35}$ Uchwata Rady Naukowej IBL PAN, http://wyborcza.pl/1,79328,4009846.html [dostęp 23.12.2014].

${ }^{36}$ Uchwała Prezydium PAN, http://wyborcza.pl/1,79328,4013712.html [dostęp 23.12.2014].

${ }^{37}$ Uchwata Rady Naukowej IBL PAN, op. cit.
} 
$\mathrm{Na}$ szczególną uwagę zasługuje stanowisko Senatu Chrześcijańskiej Akademii Teologicznej w Warszawie z dnia 27 marca $2007 \mathrm{r}^{38}$ ze względu na wyznaniowy charakter samej uczelni i odwołujący się do wartości chrześcijańskich sposób argumentacji. Senat Chrześcijańskiej Akademii Teologicznej rozpoczął prezentację swojego stanowiska od przypomnienia trudnej sytuacji kościołów chrześcijańskich w PRL, podkreślając tym samym, że są one szczególnie zainteresowane poznaniem prawdy na temat tamtych czasów. Jednakże badania naukowe dotyczące tamtego okresu nie powinny być wykorzystywane w bieżącej walce politycznej i ideologicznej, lecz uwzględniać złożoność tamtych czasów. Jest to - podkreśla Senat Chrześcijańskiej Akademii Teologicznej - zadanie dla historyków, nie zaś dla „urzędników uwikłanych w realizację doraźnych planów politycznych"39. Zrozumienie tamtych czasów i ich ocena wymaga przyjęcia odpowiedniej, odmiennej od tej wyrażonej w ustawie lustracyjnej, perspektywy:

Czy rzeczywiście na minione lata mamy patrzeć przez pryzmat dokumentów przygotowanych przez funkcjonariuszy organów bezpieczeństwa, na podstawie których współcześni urzędnicy państwowi wypisują świadectwa moralności? [...] Czy rzeczywiście musimy pominąć złożoność tamtych lat, ich moralny i rzeczowy wymiar? Czy musimy pominąć chrześcijańską wizję świata, ewangeliczne przykazanie miłości i szacunku dla drugiego człowieka? Czy liczy się tylko zawartość teczki funkcjonariusza - podważana w wielu procesach? Nie możemy zgodzić się na prokuratorską wizję świata podejrzliwości i cynizmu, na postawę „aroganckiego sędziego”. Podejrzliwość wobec wszystkich, domniemana wina każdego z nas narusza gwarantowaną przez Konstytucję godność człowieka.

[...] Droga chrześcijańskiej cywilizacji europejskiej nie może być drogą lustratorów, prokuratorskich podejrzeń, oskarżeń i zmuszania do samooskarżeń. Droga lustratorów prowadzi do destrukcji, do rozbicia więzi społeczności akademickiej i nigdy nie doprowadzi do szczerej i pokornej analizy własnej przeszłości ${ }^{40}$.

Senat Chrześcijańskiej Akademii Teologicznej, w imię zasad chrześcijańskich, sprzeciwił się ustawie lustracyjnej, podkreślając (oprócz odwołania się do argumentów artykułowanych w powyżej omawianych stanowiskach i dokumentach) to, że dzieli ona środowisko akademickie oraz godzi w godność człowieka.

Zdecydowanie prolustracyjne stanowisko przyjęło natomiast Niezależne Forum Akademickie. W „Liście Otwartym do wicepremiera Ludwika Dorna w sprawie lustracji nauczycieli akademickich oraz reformy szkolnictwa

\footnotetext{
${ }^{38}$ Stanowisko Senatu ChAT z dnia 27 marca 2007 r. w sprawie tzw. ustawy lustracyjnej, http:// wyborcza.pl/1,79328,4022661.html [dostęp 23.12.2014].

${ }^{39}$ Ibidem.

${ }^{40}$ Ibidem.
} 
wyższego" "41 znajdujemy negatywną diagnozę obecnego stanu polskiej nauki: ,[...] sytuacja nauki w Polsce jest zła, poza nielicznymi chlubnymi wyjątkami. Polskie uczelnie znajdują się daleko w światowych rankingach pod względem dorobku naukowego, podczas gdy najwybitniejsi polscy uczeni czasowo, lub stale pracują za granicą",42. Za ten stan rzeczy odpowiadać ma brak zdecydowanego zerwania polskiego środowiska akademickiego ze swoją przeszłością:

Wielu naukowców z tytułami profesorskimi zaczynało swą karierę naukową w latach 60.-80., kiedy konformizm polityczny był często warunkiem takiej kariery. Alternatywą był sprzeciw wobec systemu, który często oznaczał śmierć zawodową i koniec kariery naukowej.

Komunizm upadł 17 lat temu, jednak w nauce oraz edukacji nadal działa postPRL-owski „układ”. W polskich uczelniach często na stanowiskach kierowniczych są ludzie, którzy w tamtych czasach aktywnie działali w PZPR, tłumili krytykę, a nawet pracowali dla SB. Wielu z nich ma mizerny dorobek naukowy, prowadzi złą dydaktykę i sprzeciwia się reformom nauki w Polsce ${ }^{43}$.

Dlatego też lustracja środowisk akademickich jest uzasadniona, co więcej jest ona konieczna, $\mathrm{z}$ tej racji, iż środowiska akademickie niezdolne są do samooczyszczenia. W opinii sygnatariuszy listu należy odrzucić twierdzenia jakoby lustracja godziła w demokrację, naruszała godność i stała na przeszkodzie swobodzie badań naukowych. Wręcz przeciwnie, to brak lustracji na początku lat 90-tych odpowiedzialny jest za obecny fatalny stan polskiej nauki. Ponadto „współpracownicy SB i byli prominentni funkcjonariusze PZPR, nie powinni mieć wpływu na formowanie młodzieży akademickiej"44.

W opinii Niezależnego Forum Akademickiego bezzasadnym argumentem przeciwko ustawie lustracyjnej jest jej niezgodność z ustawą o szkolnictwie wyższym z 2005 r., ,gdzie nie ma ani słowa o lustracji. Ten zarzut podnoszą rektorzy, którzy tę ustawę tworzyli, i robili wszystko, aby zapisy lustracyjne w niej się nie pojawiły, mimo wniosków poselskich i głosów społeczności

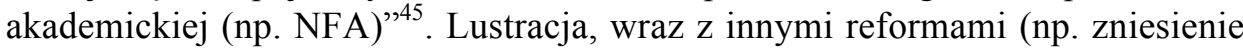
stopnia doktora habilitowanego), ma przyczynić się do poprawienia poziomu naukowego oraz konkurencyjności polskiej nauki.

Instytucje akademickie, ciała kolegialne takie jak rady wydziałów czy senaty uczelni wypowiedziały się w większości przypadków przeciwko ustawie lustracyjnej. Nie oznacza to jednak, że wypowiedziały się przeciwko lustracji jako takiej, lecz jedynie przeciwko lustracji w formie zaproponowanej przez nowelizację ustawy z dnia 14 lutego 2007 r. Pod adresem nowelizacji podniesiono

\footnotetext{
${ }^{41} \mathrm{http}: / /$ wyborcza.pl/1,79328,4026642.html [dostęp 23.12.2014].

${ }^{42}$ Ibidem.

${ }^{43}$ Ibidem.

${ }^{44}$ Ibidem.

${ }^{45}$ Ibidem.
} 
szereg zarzutów. Zarzuty te miały głównie charakter prawno-konstytucyjny, wskazywały na prawne uchybienia i braki ustawy lustracyjnej oraz zagrożenia dla porządku prawnego i państwa prawa z nią związane. Przeciwnicy zwracali uwagę na to, że ustawa lustracyjna godzi w integralność i autonomię uczelni, stoi na przeszkodzie wolności akademickich i swobody badań naukowych.

W publicznej debacie na temat ustawy lustracyjnej głos zabierały nie tylko instytucje i ciała kolegialne uniwersytetów, lecz także poszczególni przedstawiciele środowisk akademickich w Polsce. W tym przypadku odwoływano się raczej do argumentacji moralnej niż prawnej. Wydaje się to całkiem oczywiste, oficjalne dokumenty takie jak oświadczenia czy uchwały z natury swej sprzyjają odwoływaniu się do norm powszechnie obowiązujących w danych społeczeństwie, a taki charakter ma właśnie prawo stanowione. Natomiast w wypowiedziach i oświadczeniach jednostkowych, $\mathrm{z}$ natury rzeczy, ich autorzy podkreślają indywidualny, a więc moralny charakter racji przez nich przedstawianych, odwołujący się często do godności, odpowiedzialności i osobistych doświadczeń $^{46}$.

Wśród uczestników publicznej debaty panowała niemalże powszechna zgoda co do zasadności lustracji czy też rozliczenia się z przeszłością. Spór natomiast dotyczył ich formy i charakteru, a dokładniej rzecz ujmując, tego czy lustracja powinna przybrać postać przewidzianą przez nowelizację ustawy $\mathrm{z}$ dnia 14 lutego 2007 r. Fundamentalne pytanie brzmi zatem: jakim wartościom powinno służyć rozliczenie się z przeszłością?

„Każde społeczeństwo - stwierdza Wiktor Osiatyński - powinno rozliczyć się z przeszłością. Sposób, w jaki to czyni, decyduje jednak nie w mniejszym stopniu o przyszłości niż ta przeszłość, z którą próbuje sobie poradzić. Warto spojrzeć na ten proces w perspektywie wartości, jakim rozliczenie powinno służyć" ${ }^{47}$. Jedną $z$ takich wartości jest prawda, będąca podstawą zaufania. Nie można jej jednak przypisać wartości absolutnej, ograniczona bowiem może zostać przez inne wartości. Warto zatem spojrzeć na to, jak rozliczenie z przeszłością przebiegało w innych krajach. W imię jakich wartości je realizowano?

W Ameryce Łacińskiej głównym celem było ujawnienie prawdy oraz zadośćuczynienie ofiarom i ich rodzinom. Było to szczególnie ważne ze względu na tysiące ludzi zaginionych, a następnie pomordowanych, a także dzieci odbieranych rodzicom i oddawanych do adopcji wiernym ludziom reżymów. W krajach Afryki celem było wymierzenie sprawiedliwości zbrodniarzom oraz zapobieżenie na przyszłość gwałtownym konfliktom, głównie plemiennym, oraz zbrodniom popełnianym przez władców. W RPA, gdzie w okresie walki z apartheidem przemoc stosowali zarówno jego obrońcy,

\footnotetext{
${ }^{46} \mathrm{~W}$ indywidualnych wypowiedziach znaleźć możemy również i argumenty przeciwko lustracji, które podnoszone były przez instytucje akademickie: zagrożenie dla autonomii uczelni i swobody badań naukowych, niezgodność z ustawą o szkolnictwie wyższym, zbyt szeroki zakres ustawy lustracyjnej, nieproporcjonalność sankcji, itd.

${ }^{47}$ Wiktor Osiatyński, Grzech lustracji, http://wyborcza.pl/1,79328,4010401.html [dostęp 23.12.2014].
} 
jak i przeciwnicy, powołano Komisję Prawdy i Pojednania. Ci, którzy przyznali się do popełnionych czynów, zostali objęci amnestią, podczas gdy pozostali przestępcy ponosili odpowiedzialność. Celem było wybaczenie i pojednanie ${ }^{48}$.

Z powyższego cytatu wynika więc, że obok prawdy wartościami, którym służyć ma rozliczenie z przeszłością, mogą być: zadośćuczynienie ofiarom, wymierzenie sprawiedliwości prześladowcom czy wybaczenie i pojednanie. W przypadku lustracji w Polsce obok wyżej wymienionych powodów istotną przyczyną, dla której lustracja powinna zostać przeprowadzona, był także wymóg oczyszczenia środowiska akademickiego. Ta rehabilitacja miała pomóc w odbudowie autorytetu uczelni (w praktyce - osób tam pracujących).

Szczególny nacisk na oczyszczenie środowiska akademickiego kładli przede wszystkim zwolennicy ustawy lustracyjnej. Głównym powodem, dla którego się działo tak, była negatywna ocena kondycji polskiej nauki i rodzimego środowiska akademickiego, będąca konsekwencją przekonania o jego niechlubnym uwikłaniu w peerelowską przeszłość. Na konieczność oczyszczenia, jak już wspomniałem, zwracało uwagę Niezależne Forum Akademickie, uzasadniając ów wymóg krytyczną oceną polskiego środowiska akademickiego. Także prof. Zdzisław Krasnodębski w rozmowie z „Dziennikiem” zatytułowanej „Dlaczego profesorowie boją się inteligencji"49 zajął podobne stanowisko. Rozpoczął on od odrzucenia pewnego - ,zmitologizowanego” jego zdaniem - rozumienia tego, czym jest inteligencja. W przeciwieństwie do jej własnych wyobrażeń o sobie samej, zauważa prof. Krasnodębski, nie jest ona depozytariuszką uniwersalnych wartości, nie posiada uprzywilejowanego dostępu do prawdy i nie pełni funkcji krytycznych, demaskując ukryte przed oczyma innych stereotypy i ideologie. Jej pozytywna rola polega na czymś innym, a mianowicie na tym, że stanowi ona państwotwórczą, narodową elitę, jak to miało miejsce w Polsce przed II wojną światową. Jednakże po 1945 r. mamy w Polsce do czynienia z powstaniem, na polityczne zamówienie, nowej klasy, a mianowicie tzw. „inteligencji pracującej”, która, w przeciwieństwie do intelektualnej elity sprzed II wojny światowej, miała być lewicowa, postępowa, czyli miała zerwać z tradycyjnym etosem inteligenckim ${ }^{50}$. Cechą charakterystyczną owej inteligencji jest specyficzne pojmowanie nowoczesności i europejskości, odznaczające się wstydem przed polskością. Ucieleśnieniem politycznego projektu inteligencji pracującej jest inteligencja akademicka.

\footnotetext{
${ }^{48}$ Ibidem.

${ }^{49}$ Dlaczego profesorowie boja się inteligencji, rozmowa $\mathrm{z}$ prof. Zdzisławem Krasnodębskim http://wiadomosci.dziennik.pl/opinie/artykuly/207308,dlaczego-profesorowie-boja-się-inteligencji.html [dostęp 23.12.2014].

${ }^{50} \mathrm{~W}$ podobnym duchu wypowiadał się ówczesny Prezydent RP, Lech Kaczyński, gdy w kwietniu 2007 r. na spotkaniu z naukowcami popierającymi lustrację stwierdził, iż zwolennicy ustawy lustracyjnej kultywują tradycyjny etos inteligencki, natomiast jej przeciwnicy $\mathrm{z}$ tym etosem zrywają. Zob. http://wyborcza.pl/1,79328,4054276.html [dostęp 23.12.2014].
} 
Po upadku komunizmu sytuacja polskich środowisk akademickich się nie zmieniła:

Po 1989 roku na uniwersytetach nie było żadnej reformy. Wszystkie mechanizmy obronne, jakie uniwersytety wytworzyły w czasach Peerelu - a które umożliwiały im współżycie z systemem i jednocześnie zachowanie pewnej autonomii - po 1989 roku powodowały sytuację coraz bardziej patologiczną. Blokowały jakiekolwiek zmiany w szkolnictwie wyższym. Pod naciskiem rzeczywistości zmieniały się różne obszary życia i warstwy społeczne. Dzisiejsza inteligencja akademicka jest najmniej zmienioną grupą społeczną, wciąż działającą według dawnych wzorów, w ramach niemalże tych samych instytucji. Pegeery upadły, a instytucje akademickie w znacznej mierze przetrwały $\mathrm{w}$ formie skamieliny PRL-u ${ }^{51}$.

Stąd też konieczność lustracji i rozliczenia się z przeszłością. Konieczność składania oświadczeń była pierwszą po roku 1989 szansą na oczyszczenie się, ale okazała się także wyzwaniem, któremu polskie środowiska akademickie nie sprostały. Opór przeciwko ustawie lustracyjnej nie był motywowany moralnie, lecz stanowił on próbę obrony swych partykularnych interesów. „Nie dostrzegam w nim [stwierdza prof. Krasnodębski] impulsu moralnego. Widzę tylko lęk” ${ }^{52}$. Dzieje się tak, bowiem „nie mamy takich elit jak w roku 1918, gdy tworzyła się II RP, nie mamy tamtej inteligencji, lecz tylko tę stłamszoną i upodloną w PRL-u, która nie ma odwagi spojrzeć w lustro i dokonać samooczyszczenia" ${ }^{, 53}$.

Przeciwnicy lustracji motywowali - wbrew powyższym uwagom - swój sprzeciw wobec ustawy lustracyjnej odwołując się głównie do racji moralnych i do bardziej złożonego obrazu przeszłości. W okresie PRL-u mieliśmy do czynienia z szerokim spektrum ludzkich postaw, których nie da się sprowadzić do dwóch kategorii: tych, którzy nie współpracowali (i dziś można ich określać mianem bohaterów) oraz tych, którzy współpracowali (obecnie zasługują oni na potępienie. Stąd też postulat oczyszczenia jest bezzasadny. Wiele osób popiera postulat oczyszczenia, zauważa dr Krzysztof Fordoński (Uniwersytet Warszawski), często $z$ powodu

ignorancji, bo PRL to dla nich komedie Barei, świat szary i nieprzyjemny, ale przecież w sumie zabawny i niegroźny. W podobnych poglądach utwierdzają ich pryszczaci lustracji jak np. dr Dudek głoszący pogląd, że SB pozyskiwało ludzi „za pomocą perswazji i rozmaitych bonusów” - a nie dodaje, że w PRL „bonusem” mogła być większość rzeczy niezbędnych do normalnej egzystencji. Zrozumienie złożoności świata sprzed zaledwie dwudziestu lat wydaje się cechą

\footnotetext{
${ }^{51}$ Dlaczego profesorowie boją się inteligencji, rozmowa z prof. Zdzisławem Krasnodębskim, op. cit. 52 Ibidem.

${ }^{53}$ Ibidem. Emocjonalny charakter sprzeciwu wobec lustracji podkreślał także prof. Ryszard Legutko, filozof z Uniwersytetu Jagiellońskiego. Zob. Ryszard Legutko, Kto, jak nie profesorowie, powinien podlegać lustracji, http://www.pis.org.pl/article.php?id=6830 [dostęp 23.12.2014].
} 
łączącą wszystkich lustratorów podobnie jak odrzucenie możliwości, że ludzie jak i świat zmieniają się z czasem ${ }^{54}$.

Przeciwnicy ustawy lustracyjnej podkreślali złożoność rzeczywistości historycznej z dwóch powodów. Po pierwsze, wskazywali na to, że nie mamy dostępu do całej prawdy na temat współpracy ze służbami bezpieczeństwa PRL, lecz jedynie do teczek SB, których zawartości nie można obdarzyć całkowitym zaufaniem $^{55}$. Co więcej, można mieć wątpliwości co do profesjonalizmu pracowników IPN, „którzy często bez odpowiedniego przygotowania, bez dodatkowej wiedzy i bez kontekstu historycznego chcą roztrząsać w pięć minut sprawy życia i śmierci" ${ }^{56}$. Po drugie, podkreślali, że nie sposób poddać przeszłości jednoznacznej ocenie. „Niegodziwość ustawy polega [...] na tym, że proponuje jednoparametryczną ocenę ludzi: dobrzy są ci, którzy nie mieli związków ze służbami, źli, ci, którzy je mieli. Tak jakby człowiek nie był istotą nieco bardziej skomplikowaną" ${ }^{57}$.

Podobnie stawia sprawę Wiktor Osiatyński w przywoływanym już tekście Grzech lustracji. Stwierdza, iż w każdym społeczeństwie występują bohaterowie, ludzie, którzy gotowi są poświęcić się dla innych i stanowią wzór godny naśladowania. Ich istnienie jest konieczne dla przetrwania społeczeństwa, szczególnie w trudnych czasach. Bohaterowie nie stanowią jednak większości społeczeństwa, tworzą ją tzw. zwykli ludzie, którzy „wykonują swoją pracę, zarabiają na chleb, troszczą się o siebie i o swoich najbliższych" ${ }^{, 5}$. Pojawia się więc pytanie, jaką miarą sądzić przeszłość. Czy przykładać doń miarę bohaterstwa, czy zwykłego człowieka? Wiktor Osiatyński odpowiada na to pytanie w sposób następujący:

54 Krzysztof Fordoński, Nie da się zbudować zdrowia społecznego na krzywdzie, http://wyborcza.pl/1,79328,4011342.html [dostęp 23.12.2014]. Jest to polemika z tekstem dra hab. Wojciecha Krzysztofiaka, Przypadek kapitana Cholewy, http://wyborcza.pl/1,79328,4011344.html [dostęp 23.12.2014].

${ }^{55}$ Uwage na to zwraca m.in. prof. Hanna Świda-Ziemba w rozmowie z „Dziennikiem” zatytułowanej Uniwersytet na straży wartości, http://wiadomosci.dziennik.pl/opinie/artykuly/ 207162, uniwersytet-na-strazy-wartosci.html [dostęp 23.12.2014]. W niniejszej rozmowie prof. Hanna Świda-Ziemba wskazuje także na to, że często większą szkodę od tajnych współpracowników na uniwersytetach wyrządzali partyjni funkcjonariusze. Często także nie donoszono do SB, lecz do partyjnych komórek. W aktach IPN nie znajdziemy natomiast śladu tegoż, przez co nasz obraz rzeczywistości tamtych czasów będzie wypaczony.

56 Prof. Jan M. Piskorski (historyk, Uniwersytet Szczeciński) http://wyborcza.pl/1,79328, 4016542.html [dostęp 23.12.2014].

${ }^{57}$ Jerzy Jarzębski, Władza nienawidzi ludzi myślacych samodzielnie, http://wyborcza.pl/1,79328, 4013901.html [dostęp 23.12.2014].

58 Wiktor Osiatyński, Grzech lustracji, http://wyborcza.pl/1,79328,4010401.html [dostęp 23.12.2014]. 
A ja domagam się praw dla tych, którzy dali sobie złamać kręgosłup, coś podpisali, a jednocześnie starali się nie szkodzić innym. Którzy ulegli przemocy, uznając, że najwyższe obowiązki mają wobec najbliższych. Że mają troszczyć się o żonę lub męża, o dzieci, o to, by te nie były głodne, opuszczone i zaniedbane. Taka postawa nie musi zasługiwać na uznanie, ale też nie może stanowić podstawy potępienia. Domagam się w imieniu tych ludzi prawa do tego, by nie być bohaterem. Jednocześnie odmawiam bohaterom prawa, by oceniali innych swoją miarą i wymagali od nich bohaterstwa. Zwłaszcza wstecz. Taka postawa jest przejawem pychy. Zresztą przeważająca większość prawdziwych bohaterów nie osądza ludzi i studzi zapędy radykalnych lustratorów ${ }^{59}$.

Postawa taka nie oznacza rezygnacji $\mathrm{z}$ rozliczenia przeszłości, lecz ograniczenie moralnego potępienia do tych, którzy bezsprzecznie zasługują na miano zdrajcy. Taki punkt widzenia jest konsekwencją odejścia od czarno-białej wizji przeszłości, i tym samym, od zdecydowanie negatywnej oceny obecnego stanu polskiego środowiska naukowego.

Stojący za ustawą lustracyjną czarno-biały obraz przeszłości i negatywna ocena obecnego stanu nauki w Polsce nie były głównymi powodami, dla których została ona odrzucona przez część polskiego środowiska akademickiego. W wątpliwość poddawana została także sama zasadność rozliczenia się z przeszłością przy pomocy środków prawnych, jak i forma, w jakiej lustracja w postaci przewidzianej przez ustawę miała zostać przeprowadzona.

Rozliczenie z przeszłością nie musi mieć charakteru prawnego. Co więcej, krytycy takiego rozwiązania wskazywali nie tylko na jego nieadekwatność, lecz także na niebezpieczeństwa z nim związane. Dr Wojciech Baluch (UJ) stwierdzał, że konieczność składania oświadczeń lustracyjnych (przewidziana dla osób pełniących funkcje publiczne przez ustawę z 1997 r.) była w istocie rzeczy pewnym sposobem na obejście prawa, bowiem ,współpraca $z$ reżimem PRL-

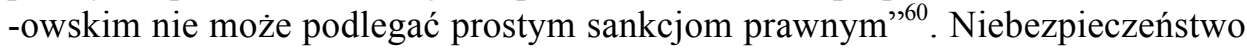
z tym związane polegać miało na tym, że ,precedens ten otworzył drogę do obchodzenia porządku prawnego, który uznaje pewne działania za naganne, często niegodne, ale niepodlegające publicznemu procesowi zakończonemu wymierzeniem kary" "61. Innymi słowy - to, co uchodziło za moralnie naganne, może stać się przestępstwem i to przestępstwem, z którego należy się publicznie „wyspowiadać”. „Czy w imię prawdy oraz przejrzystości życia publicznego - zapytuje retorycznie Wojciech Baluch - posłowie i posłanki nie powinni składać oświadczeń, w których zapewnią, że nigdy nie uderzyli swojego małżonka. Albo, żeby przywołać mniej drastyczny przykład, czyż pracownicy naukowi i nauczyciele nie powinni publicznie wyznać, czy nie ściągali lub

\footnotetext{
${ }^{59}$ Ibidem.

${ }^{60}$ Wojciech Baluch, To wzajemne wyniszczenie, http://wyborcza.pl/1,79328,3978020.html [dostęp 23.12.2014].

${ }^{61}$ Ibidem.
} 
korzystali z pomocy egzaminatorów (widziałem i takie przypadki) w czasie matury lub ważnych egzaminów wstępnych" ${ }^{\text {"2 }}$ ? Podobne wątpliwości zgłaszała prof. Elżbieta Kałuszyńska (Uniwersytet Warmińsko-Mazurski w Olsztynie), wskazując na złożoność dziedziny moralności i nieadekwatność prawnych rozstrzygnięć w tej dziedzinie: „Uprawianie moralności przy pomocy dekretów i państwowego aparatu represji przypomina operację na otwartym mózgu przy pomocy siekiery. Moralność, problem sumienia, winy to zbyt delikatna materia. Tylko dwa przykazania z Dekalogu weszły do kodeksów karnych, a i tak o winie w każdym indywidualnym przypadku rozstrzyga sąd, przy domniemaniu niewinności" ${ }^{63}$.

Ostatnia uwaga jest tutaj warta podkreślenia. Jak pamiętamy, sprzeciw wobec ustawy lustracyjnej budziła także jej forma, natomiast jednym z zarzutów podnoszonych przez środowiska akademickie było, że ustawa lustracyjna wprowadzając wymóg składania oświadczeń lustracyjnych łamie zasadę prawną, która mówi, że nikogo nie można zmuszać do przedstawiania dowodów przeciwko sobie samemu. W przypadku indywidualnych wypowiedzi podkreślano także to, że wymóg składania oświadczeń lustracyjnych narusza godność tych, którzy zobowiązani są to czynić. Zmusza bowiem jednostki do upokarzającej czynności dowodzenia swojej niewinności. Co więcej, wskazywano także na zbędność oświadczeń lustracyjnych, skoro i tak przez IPN będą publikowane listy współpracowników Służby Bezpieczeństwa PRL ${ }^{64}$.

Przewidziane dwa tryby lustracji - jeden polegający na składaniu oświadczeń lustracyjnych, drugi na udostępnieniu list współpracowników SB - każą zadać pytanie, czemu zostały wprowadzone, skoro ten ostatni wystarczy do tego, by ujawnić tajnych współpracowników? Odpowiedzi udzielane na to pytanie przez przeciwników ustawy lustracyjnej wskazywały na pozamerytoryczne powody wprowadzenia oświadczeń lustracyjnych: próbę wasalizacji różnych środowisk (w tym środowiska akademickiego w Polsce), zmuszenie ich przedstawicieli do aktów wiernopoddaństwa itp. Innymi słowy - ustawa lustracyjna przez część środowiska akademickiego postrzegana była jako narzędzie walki politycznej $j^{65}$.

\footnotetext{
${ }^{62}$ Ibidem.

${ }^{63}$ List prof. Kaluszyńskiej: Nie wolno nam się na to godzić, http://wyborcza.pl/1,79328, 4006282.html [dostęp 23.12.2014].

${ }^{64}$ Witold Marciszewski, Przynajmniej nie będę się wstydził za siebie, http://wyborcza.p1/1,79328, 4018583.html [dostęp 23.12.2014].

${ }^{65}$ Zob. np. rozmowę z Henrykiem Samsonowiczem Uniwersytety zawsze zagrożone, http:// wyborcza.pl/1,79328,4041319.html [dostęp 23.12.2014], list prof. Kałuszyńskiej: Nie wolno nam się na to godzić, op. cit.
} 
Wbrew opinii zwolenników ustawy lustracyjnej, że przestrzeganie prawa w państwie demokratycznym jest moralnym i politycznym wymogiem ${ }^{66}$, sprzeciw wobec niej przez jej przeciwników postrzegany był jako uprawniony akt obywatelskiego nieposłuszeństwa lub sprzeciwu sumienia, bowiem ci, którzy się nań decydują - zauważa przywoływany już Wojciech Baluch - nie krzywdzą nikogo i gotowi byli ponieść koszty odmowy złożenia oświadczenia lustracyjnego ${ }^{67}$. Lustracja, w formie przewidzianej przez ustawę lustracyjną, w opinii jej przeciwników stała $\mathrm{w}$ sprzeczności $\mathrm{z}$ wieloma zasadami państwa prawa, naruszała autonomię uczelni i swobodę badań naukowych, forsowała czarno-białą wizję historii, była nieuprawnioną próbą „legalizacji” moralności, naruszała godność jednostek zmuszonych do składania oświadczeń lustracyjnych, służyła przede wszystkim doraźnym celom politycznym, nie zaś prawdzie i pojednaniu. W opinii jej zwolenników służyła natomiast oczyszczeniu środowiska akademickiego, utwierdzeniu autorytetu nauczyciela akademickiego, wymierzeniu sprawiedliwości - docenieniu bohaterów i ukaraniu winnych współpracy, zaś sprzeciw wobec niej był wyrazem albo pewnego złudzenia, albo odruchem tych, którzy boją się utraty własnej pozycji i mają coś do ukrycia.

\section{BIBLIOGRAFIA}

Baluch, Wojciech, To wzajemne wyniszczenie, http://wyborcza.pl/1,79328,3978020.html [dostęp 23.12.2014].

Dlaczego profesorowie boja się inteligencji, rozmowa $\mathrm{z}$ prof. Zdzisławem Krasnodębskim, http://wiadomosci.dziennik.pl/opinie/artykuly/207308,dlaczego-profesorowie-boja-sieinteligencji.html, [dostęp 23.12.2014].

Fordoński, Krzysztof, Nie da się zbudować zdrowia społecznego na krzywdzie, http://wyborcza.pl/ 1,79328,4011342.html [dostęp 23.12.2014].

Jarzębski, Jerzy, Władza nienawidzi ludzi myślacych samodzielnie, http://wyborcza.pl/ 1,79328,4013901.html [dostęp 23.12.2014].

Krzysztofiak, Wojciech, Przypadek kapitana Cholewy, http://wyborcza.pl/1,79328,4011344.html [dostęp 23.12.2014].

Legutko, Ryszard, Kto, jak nie profesorowie, powinien podlegać lustracji, http://www.pis.org.pl/ article.php?id=6830 [dostęp 23.12.2014].

List otwarty do wicepremiera Ludwika Dorna w sprawie lustracji nauczycieli akademickich oraz reformy szkolnictwa wyższego, Niezależne Forum Akademickie, http://wyborcza.pl/1,79328, 4026642.html [dostęp 23.12.2014].

List otwarty $w$ sprawie lustracji na Uniwersytecie Jagiellońskim, http://wyborcza.pl/1,79328, 4033504.html [dostęp 23.12.2014].

List prof. Elżbiety Kałuszyńskiej: „,Nie wolno nam się na to godzič”, http://wyborcza.p1/1,79328, 4006282.html [dostęp 23.12.2014].

${ }^{66}$ List prof. dr hab. Juliusza Sztychmilera, http://wyborcza.pl/1,79328,4019050.html [dostęp 23.12.2014]: „[...] bunt przeciw ustawie, wzywanie do nieprzestrzegania jej postanowień - stwierdza Juliusz Sztychmiler - jest anarchią i brakiem demokracji”.

${ }^{67}$ Wojciech Baluch, To wzajemne wyniszczenie, http://wyborcza.pl/1,79328,3978020.html [dostęp 23.12.2014]. 
List prof. Juliusza Sztychmilera, http://wyborcza.pl/1,79328,4019050.html [dostęp 23.12.2014].

Marciszewski, Witold Przynajmniej nie będę się wstydzit za siebie, http://wyborcza.pl/1,79328, 4018583.html [dostęp 23.12.2014].

Odpowiedź na uchwate Senatu Uniwersytetu Warszawskiego, https://nfa.pl/news.php?id=5416\& PHPSESSID=a90dd83a03a16a5b0498ae060a424df7 [dostęp 23.12.2014].

Osiatyński, Wiktor, Grzech lustracji, http://wyborcza.pl/1,79328,4010401.html [dostęp 23.12. 2014].

Piskorski, Jan M., Lustracja na Uniwersytecie Szczecińskim, http://wyborcza.p1/1,79328,4016542. html [dostęp 23.12.2014].

Stanowisko 175 Konferencji Rektorów Uniwersytetów Polskich z dnia 23 marca 2007 roku w sprawie tzw. ustawy lustracyjnej, https://www.umk.pl/uczelnia/dokumenty/biuletyn/prawo/ inc/zalaczniki/Uchwala_17_2007_z1.pdf [dostęp 23.12.2014].

Stanowisko Rady Wydzialu Prawa i Administracji Uniwersytetu Warszawskiego z dnia 19 marca 2007 r. w sprawie tzw. ustawy lustracyjnej, http://wyborcza.pl/1,79328,4003768.html [dostęp 23.12.2014].

Stanowisko Senatu Chrześcijańskiej Akademii Teologicznej z dnia 27 marca 2007 r. w sprawie tzw. ustawy lustracyjnej, http://wyborcza.pl/1,79328,4022661.html [dostęp 23.12.2014].

Uchwała Prezydium PAN, http://wyborcza.pl/1,79328,4013712.html [dostęp 23.12.2014].

Uchwata Rady Naukowej Instytutu Badań Literackich PAN, http://wyborcza.pl/1,79328, 4009846.html [dostęp 23.12.2014].

Uchwata Rady Wydziatu Filozoficznego Uniwersytetu Jagiellońskiego z dnia 27 marca 2007 r., http://wyborcza.pl/1,79328,4018318.html [dostęp 23.12.2014].

Uchwata Rady Wydzialu Prawa i Administracji Uniwersytetu Warszawskiego z dnia 19 marca 2007 r. w sprawie zagrożeń dla demokratycznego państwa prawnego, http://wyborcza.pl/ 1,79328,3999054.html [dostęp 23.12.2014].

Uchwała Senatu Uniwersytetu im Adama Mickiewicza nr 17 z dnia 27 marca 2007 roku, http://www.umk.pl/uczelnia/dokumenty/biuletyn/prawo/?akcja=dokument\&typ=Uchwaly\&nr $=17 \& \mathrm{bp}=0 \& \mathrm{rok}=2007$ [dostęp 23.12.2014].

Uchwała Senatu Uniwersytetu Jagiellońskiego z dnia 28 marca 2000 r., http://wyborcza.pl/ 1,79328,4022659.html [dostęp 23.12.2014].

Uchwata Senatu Uniwersytetu Warszawskiego nr 181 z dnia 21 marca 2007 r. w sprawie zagrożeń dla demokratycznego państwa prawnego, http://www.monitor.uw.edu.pl/Lists/Uchway/ Attachments/1899/M.2007.199.U.181.pdf [dostęp 23.12.2014].

Uchwata Senatu Uniwersytetu Warszawskiego nr 182 z dnia 21 marca 2007 r. w sprawie tzw. ustawy lustracyjnej, http://www.monitor.uw.edu.pl/Lists/Uchway/Attachments/1900/M.2007. 200.U.182.pdf [dostęp 23.12.2014].

Uniwersytet na straży wartości, rozmowa $\mathrm{z}$ prof. Hanną Świdą-Ziembą, http://wiadomosci. dziennik.pl/opinie/artykuly/207162,uniwersytet-na-strazy-wartosci.html [dostęp 23.12.2014].

Uniwersytety zawsze zagrożone, rozmowa $\mathrm{z}$ prof. Henrykiem Samsonowiczem, http:// wyborcza.pl/1,79328,4041319.html [dostęp 23.12.2014],

Woleński, Jan, List otwarty w sprawie lustracji na UJ, http://wyborcza.pl/1,79328,4053937.html [dostęp 23.12.2014].

—_ Lustracja jako zwierciadto, Universitas, Kraków 2007.

\section{RESPONSES FROM ACADEMIC COMMUNITY TO LUSTRATION BILL}

The article describes a response from academic communities - both collegial bodies and individuals - to so-called lustration bill. Opponents and supporters of the lustration bill present both formal and legal arguments, and moral ones. The aim of the article is to an adequate depiction of the response from academic communities to the lustration bill.

Keywords: academic life in Poland, lustration, responsibility for the past 